DUŠAN BOJKOVIĆ, doktorand

Filozofski fakultet, Odeljenje za istoriju

Beograd

UDK 329.15:323.1(497.115)"1937/1941"

323.1(497.115)"1937/1941"

\title{
NACIONALNA POLITIKA KOMUNISTIČKE PARTIJE JUGOSLAVIJE NA KOSOVU I METOHIJI 1937-1941
}

\begin{abstract}
APSTRAKT: Analizirajući tekstove rezolucija kongresa, konferencija i proglasa Komunističke partije Jugoslavije nastojali smo da prikažemo osnovne tendencije u nacionalnoj politici jugoslovenskih komunista prema srpskom narodu i šiptarskoj nacionalnoj manjini na Kosovu i Metohiji u periodu od obnove partijskih struktura u Srbiji 1937. do početka Drugog svetskog rata u Kraljevini Jugoslaviji 1941. Istraživanje je zasnovano na dokumentima pohranjenim u Arhivu Jugoslavije, objavljenim izvorima partijske provenijencije, tekstovima vodećih jugoslovenskih komunista i literaturi.
\end{abstract}

Ključne reči: Kosovo i Metohija, Komunistička partija Jugoslavije, Srbi, Šiptari (Arnauti, Albanci), Oblasni komitet, velikosrpski hegemonizam, samoopredeljenje

Usled sve snažnijeg uticaja Komunističke internacionale (KI, Kominterna) na prilike u Komunističkoj partiji Jugoslavije (KPJ) početkom 20-ih godina prošlog veka, jugoslovenski komunisti započeli su reviziju svojih stavova. Najpre je činu stvaranja Kraljevine Srba, Hrvata i Slovenaca decembra 1918. oduzet progresivni karakter, iako je ujedinjenje „po prvi put tih triju jugoslovenskih nacija, koje su se ranije nalazile pocepane pod jarmom austro-ugarskog imperijalizma“, značilo „stvaranje objektivnih uslova za proces formiranja jedne nacije iz triju srodnih nacija“. ${ }^{1}$ Iznad svega, utemeljeno je mišljenje da je formiranje zajedničke države Srba, Hrvata i Slovenaca jedan od rezultata Prvog svetskog rata, odnosno Pariske mirovne konferencije.

Počev od Treće zemaljske konferencije KPJ, održane januara 1924, $\mathrm{u}$ retorici jugoslovenskih komunista prevagu je odnelo stanovište $\mathrm{u}$ korist svrgavanja „velikosrpske buržoazije“ i borbe „za obezbeđenje svakog naroda

${ }^{1}$ Istorijski arhiv Komunističke partije Jugoslavije (dalje IA KPJ), tom II, Kongresi i zemaljske konferencije KPJ 1919-1937, Beograd 1949, 68. 
da se samoopredeli, sa svima konzekvencama koje to pravo za sobom povlači“. Prema mišljenju rukovodstva KPJ, „osnovni uzrok zaoštravanja nacionalnih suprotnosti leži na strani srpske buržoazije“, koja sprovodi „nacionalnu hegemoniju protiv hrvatskog i slovenačkog naroda“. Takođe, „ona uništava autonomiju Crne Gore i najgrubljim nacionalnim ugnjetavanjem, kolonizacijom i nasilnim istrebljivanjem i asimilacijom srbizira [Vardarsku] Makedoniju i potiskuje nacionalne manjine“. ${ }^{2}$

Novo rukovodstvo KPJ na čelu sa Đurom Đakovićem, postavljeno maja 1928. od strane Kominterne, dodatno je razradilo teze KPJ o nacionalnom pitanju. Pravo na "samoopredeljenje do potpunog otcepljenja“ prošireno je na nacionalne manjine, pri čemu se u prvom redu mislilo na Mađare i Nemce u Vojvodini i „Arnaute“ na Kosovu i Metohiji. Na Četvrtom, tzv. Drezdenskom kongresu KPJ (1928) govorilo se o borbi protiv posrbljavanja „trećine albanskog naroda“, ${ }^{3}$ koji se nakon Prvog svetskog rata našao pod „vladavinom velikosrpske buržoazije“. S tim u vezi, KPJ „izjavljuje solidarnost revolucionarnih radnika i seljaka ostalih nacija Jugoslavije [odnosno Kraljevine SHS - D. B.], a pre svega Srbije, s albanskim nacionalno-revolucionarnim pokretom u licu Kosovskog komiteta i poziva radničku klasu da svestrano pomaže borbu raskomadanog i ugnjetenog albanskog naroda za nezavisnu i ujedinjenu Albaniju“. Mada granice „albanskog područja“ unutar Kraljevine SHS nisu jasno određene, u dokumentima KPJ govori se o „aneksiji albanskih krajeva u zaposednutoj Makedoniji i na Kosovu“."

$\mathrm{U}$ propagandi jugoslovenskih komunista $\mathrm{u}$ međuratnom periodu uporno je ukazivano na ugroženost šiptarskog stanovništva na Kosovu i Metohiji. U „Pismu iz Ipeka [Peći - D. B.]“ objavljenom u Proleteru početkom 1930, stoji kako od 1912, kada je Kraljevina Srbija „zauzela“ Kosovo i Metohiju, Srbi „progone Albance, oduzimaju im zemlju, nameću globe, pale kuće, muče žene i decu, a odrasle ubijaju“. Pri tom je kačačko odmetništvo

${ }^{2}$ Isto, 65,69 .

3 U međuratnom periodu u dokumentima Komunističke partije Jugoslavije i Komunističke internacionale termini „Arnauti“, „Arbanasi“, „Šiptari“, „Albanci“ predstavljaju sinonime. Ipak, nije uvek jasno šta se u retorici KPJ podrazumeva pod odrednicom „albansko područje“ ili „albanske zemlje“ izvan granica albanske države. Drugim rečima, nejasno je da li se time želelo naglasiti da određene oblasti pripadaju šiptarskom (arnautskom, albanskom) stanovništvu po prirodnom ili istorijskom pravu. U ovom radu prednost je data izvorima. Stoga prikladnim smatramo termine „Šiptari“ i „Arnauti“, odnosno „šiptarsko stanovništvo“ i „šiptarska nacionalna manjina“, koji su u prvoj polovini 20 . veka najčešće upotrebljavani u dokumentima partijske provenijencije. U daljem tekstu termin „Albanci“ rezervisan je za stanovnike albanske države, dok je albansko stanovništvo u okolnim zemljama - u Jugoslaviji i Grčkoj - određeno kao šiptarska ili arnautska nacionalna manjina.

${ }^{4}$ Isto, 154, 163, 182-183. 
opravdano kao „normalna“ posledica pokušaja „srbiziranja Kosova i Metohije“. ${ }^{5}$

Sredinom 30-ih godina određeni radikalni stavovi KPJ o pitanju odnosa prema jugoslovenskoj državi umnogome su ublaženi. U tekstu Akcionog programa komunističke partije za selo, usvojenom na Četvrtoj zemaljskoj konferenciji KPJ decembra 1934, potvrđeno je „pravo samoodređenja do otcepljenja svim potlačenim narodima - Hrvatima, Slovencima, Makedoncima, Crnogorcima“, ali ne i nacionalnim manjinama. Albansko pitanje razmatrano je jedino u kontekstu vraćanja „šuma i pašnjaka koje su oteli srpski kapitalisti i veleposjednici općinama Makedonije i Kosova i plemenima Crne Gore“. Komunisti su istupali „protiv poreskog pljačkanja stanovništva u nesrpskim krajevima“, pri čemu se, pored ostalog, mislilo na oblasti naseljene šiptarskim življem. Takođe, istaknut je zahtev za korišćenje albanskog jezika u ,školi, na sudu i u vojsci“ u krajevima naseljenim Šiptarima. Istovremeno je zahtevan „progon srpskih okupatora, srpskih trupa, činovnika, žandarma, kao i četnika" sa „Kosova“. ${ }^{6}$

U međuratnom periodu unutar krugova jugoslovenskih komunista nije jasno definisan odnos prema Kosovu i Metohiji. U tekstu Rezolucije Četvrte zemaljske konferencije KPJ najpre je zauzeto stanovište u prilog formiranja „radničke i seljačke sovjetske vlade“ na „Kosovu“. U daljem tekstu, međutim, nema pomena o individualizaciji ove oblasti. ${ }^{7}$

Počev od sredine 30-ih godina u napisima vodećih jugoslovenskih komunista prostor Kosova i Metohije izuzet je iz korpusa „istorijskih pokrajina" u okviru jugoslovenske zajednice. Prema Josipu Čižinskom u sastav Kraljevine Jugoslavije ulaze „Srbija, Hrvatska, Dalmacija, Slovenija, Vojvo-

${ }^{5}$ Proleter, br. 10, januar 1930, 5. Prema istraživanjima Zorana Janjetovića, nakon Balkanskih ratova 1912-1913, samo se manji deo srpskih kolonista naselio na Kosovu i Metohiji. Kako su u toku Prvog svetskog rata poništeni rezultati kolonizacije, doneta je 24 . septembra 1924. Uredba o naseljavanju južnih krajeva. Uredba je dobila snagu zakona 11. juna 1931. i ostala je na snazi do 24. juna 1933, kada je izmenjena i dopunjena. Počev od 1936. jugoslovenske vlasti su uvidele da agrarna politika (kolonizacija) na Kosovu i Metohiji nije dala željene rezultate, te je započeto obimnije oduzimanje zemlje od šiptarskih posednika. Predviđeno je da zemljišni posed ne prelazi 0,40 hektara po članu domaćinstva. Ova mera je privremeno zaustavljena 1939. Više: Z. Janjetović, Deca careva, pastorčad kraljeva. Nacionalne manjine u Jugoslaviji 1918-1941, Beograd 2005, 326-328, 331. Pojedini autori navode kako je nakon Drugog svetskog rata utvrđeno da međuratna kolonizacija nije ugrožavala šiptarsko stanovništvo, jer je naseljenicima dodeljivana slobodna državna zemlja utrine ili trajno napuštena dobra. - M. Pavlović, Srbi na kraju Drugog svetskog rata, Istorija 20. veka, br. 1-2/1993, Beograd 1993, 161. Prema popisu stanovništva iz 1939. na Kosovu i Metohiji živelo je 645.017 duša: $65,5 \%$ neslovenskog porekla - od toga $350.946(54,4 \%)$ „Arbanasa“ - i 217.746 (29,8\%) Srba. Udeo međuratnih kolonista iznosio je 9,2\% (52.294). V. Jovanović, Vardarska banovina 1929-1941, Beograd 2011, 44.

${ }^{6}$ IA KPJ, tom II, 264-265.

${ }^{7}$ Isto, 266, 268. 
dina, Bosna, Crna Gora i Makedonija“. ${ }^{8}$ Josip Broz se u pismu od 2. novembra 1936. upućenom Veselinu Masleši (tzv. „Pismo za Srbiju“) zalagao za „slobodnu zajednicu svih naroda Jugoslavije u sadanjim granicama, uređenu po federativnoj osnovi, a protiv svakog ugnjetavanja i hegemonije bilo kojeg naroda po drugome“. Prema njegovom mišljenju „hrvatski, slovenački, srpski, makedonski i crnogorski narod treba da se na demokratski način izjasne kako žele da urede svoje međusobne odnose $u$ državnoj zajednici. Isto tako, narod u Vojvodini i Bosni i Hercegovini ima pravo da se izjasni o svom odnosu u državnoj zajednici“. U tom smislu, Josip Broz je predlagao raspisivanje izbora na pokrajinskom nivou, „radi toga da bi Hrvati, Slovenci, Srbi, Makedonci, Crnogorci, pa i Vojvodina i Bosna i Hercegovina mogli da formiraju svoje nacionalne skupštine (sabore), koji bi suvereno odlučivali o svojim nacionalnim i regionalnim zahtjevima i državnom uređenju“. ${ }^{9}$

U partijskim dokumentima nisu navedeni uzroci usled kojih je došlo do promene odnosa KPJ prema Kosovu i Metohiji posle Drezdenskog kongresa, na kome je zauzeto nedvosmisleno stanovište o izdvajanju ove oblasti u cilju ujedinjenja albanskog naroda u jednu homogenu državu.

Na Sedmom kongresu Kominterne (1935) proklamovana je politika narodnog fronta, koja je podrazumevala udruživanje svih radničkih i demokratskih partija u Evropi. Razmatrajući problem teritorijalnih aspiracija fašističkih sila u usponu, pre svega Nemačke i Italije, u Moskvi je ocenjeno da bi očuvanje teritorijalne celovitosti malih evropskih država išlo u korist svetskog radničkog pokreta.

Od sredine 1937, a pogotovo od marta 1938, jugoslovenski komunisti su glavninu svoje propagandne delatnosti usmerili ka pripremi odbrane granica Kraljevine Jugoslavije od revanšističkih zahteva susednih fašističkih država. U tom smislu, najpre je trebalo obnoviti i ojačati partijske strukture u zemlji. Centralni komitet (CK) KPJ poslao je decembra 1937. Rodoljuba Čolakovića u Kraljevinu Jugoslaviju, sa zadatkom da kao predstavnik KPJ pomogne rad partijskog rukovodstva i uspostavi vezu sa pokrajinskim rukovodstvima u Bosni i Hercegovini, Makedoniji, Crnoj Gori i na Kosovu i Metohiji. Posebno je trebalo učvrstiti partijsko rukovodstvo u Srbiji i razviti širu antifašističku aktivnost u okviru narodnog fronta. Brojna i opsežna hapšenja tokom 1936. i 1937. dovela su do drastičnog opadanja političke aktivnosti komunista u Srbiji. ${ }^{10}$ Sreten Žujović („N. Životić“)

${ }^{8}$ Revolucija pod okriljem Kominterne. Izabrani spisi Milana Gorkića. Priredio i predgovor napisao Božidar Jakšić, Beograd 1997, 220.

${ }_{9}$ Arhiv Jugoslavije, fond Komunistička internacionala (dalje AJ, KI), 1936/374.

${ }^{10}$ Novembra 1936. u Srbiji je uhapšeno oko 150 komunista, najvećim delom partijskih rukovodilaca. U potpunosti su likvidirani beogradski Mesni komitet i nekoliko rejonskih komiteta. Sledeće godine, u leto 1937, uhapšeni su svi članovi Oblasnog komiteta za 
pisao je septembra 1937. u Proleteru kako se u Srbiji „naročito oseća zaostalost“ po pitanju „vaspitanja, podizanja i razvitka naših kadrova, za uzdizanje njihovog političkog nivoa, razvijanje njihove aktivnosti i sopstvene inicijative i njihove uloge i odgovornosti u rukovođenju partijom“". ${ }^{11} \mathrm{Na}$ Petoj pokrajinskoj konferenciji KPJ za Srbiju, održanoj najverovatnije početkom maja 1940. u Beogradu, određeni su zadaci partijskih organizacija u Srbiji: „[1] borba za izgradnju, jačanje i čistoću partije; [2] ostvarenje jedinstva radničke klase; [3] ostvarenje borbenog saveza radnika i seljaka; [4] neumorna borba za slobodu i ravnopravnost svih ugnjetenih naroda“. ${ }^{12}$

Tokom druge polovine 1937. Centralni komitet KPJ obrazovao je Pokrajinski komitet (PK) KPJ za Srbiju, na čelu sa Aleksandrom Rankovićem. Uoči rata PK se sastojao od Biroa kao užeg tela (Aleksandar Ranković, Milovan Đilas, Spasenija Babović) i proširenog Pokrajinskog komiteta. Piramidalna struktura PK povezivala je partijske ćelije sa instruktorima - Petar Stambolić, Miloš Minić, Svetozar Vukmanović, Svetislav Stefanović, Milan Mijalković i drugi - ili ljudima na određenim partijskim funkcijama, koji su, dalje, bili u vezi sa radničkim ćelijama ili s rejonskim komitetom. ${ }^{13}$

Posle formiranja banovina 1929. područje Kosova i Metohije ulazilo je u sastav tri banovine - moravske, zetske i vardarske. ${ }^{14}$ Kako je u međuratnom periodu, do usvajanja politike narodnog fronta 1935, ideologija KPJ u znatnoj meri počivala na negaciji aktuelnog državnog uređenja i same

centralnu Srbiju i članovi okružnih i mesnih komiteta u Kragujevcu, Kruševcu, Užicu, Ćupriji, Leskovcu, Aleksincu i Jagodini. Pod sudskom istragom nalazila su se 163 člana KPJ, dok je kroz kazamate Kraljevine Jugoslavije prošlo 500-600 osumnjičenih komunista. U Vojvodini su posle velike „provale“ novembra 1936. pohapšeni svi članovi pokrajinskog rukovodstva i 122 pripadnika KPJ iz okružnih i mesnih komiteta u Petrovgradu, Subotici, Somboru, Starom Bečeju, Novom Sadu i Vršcu. Više: Pregled istorije Saveza komunista Jugoslavije, Beograd 1963, 240-242; AJ, KI, 1936/3; 1936/22; 1936/32.

${ }_{11}^{11}$ Proleter, br. 10, septembar 1937, 8.

${ }^{12}$ Izvori za istoriju SKJ, Peta zemaljska konferencija KPJ, tom I, knj. 10, Beograd 1980, 267-268. U radu Pete pokrajinske konferencije KPJ za Srbiju učestvovala su 33 delegata, izložena su dva referata, izabrano novo pokrajinsko rukovodstvo i 17 delegata za predstojeću Petu zemaljsku konferenciju KPJ.

${ }^{13}$ Više: M. Marković, Sazrevanje revolucije (Sećanja 1931-1941), Beograd 1984, 63102, 133-136; M. Folić, Konsolidacija Komunističke partije Jugoslavije na Kosovu u periodu 1937-1941. godine, Tokovi revolucije, br. 6/1971, Beograd 1971, 3-14; V. Glišić, Dosije o Blagoju Neškoviću. Prilozi za biografiju, Beograd 2011, 15-16.

14 Želja kralja Aleksandra I Karađorđevića bila je da podelom jugoslovenske države na deset administrativnih oblasti dodatno učvrsti centralizaciju zemlje. Negacijom istorijskih pokrajina, s druge strane, vodilo se računa o jačanju srpskog elementa u novoformiranim banovinama. Više: B. Petranović, M. Zečević, Agonija dve Jugoslavije, Beograd 1991, 9092. U istoriografiji postoji stanovište prema kome je uvođenje banovina više štete nanosilo srpskim nacionalnim interesima nego hrvatskim ili slovenačkim. - B. Gligorijević, Unutrašnje (administrativne) granice Jugoslavije između dva svetska rata 1918-1941, Istorija 20. veka, br. 1-2/1992, Beograd 1992, 32. 
Kraljevine Jugoslavije, komunisti u svojoj partijskoj organizaciji nisu poštovali novonastale prilike na terenu. U strukturi Partije zadržana je ranija podela na pokrajinske, oblasne, okružne i mesne komitete. U zvaničnim dokumentima KPJ iz međuratnog perioda prostor Srbije nije jasno definisan, ali se Kosovo i Metohija, Sandžak i Vojvodina često navode kao posebne jedinice ili pokrajine $u$ jugoslovenskoj zajednici.

Po pitanju Kosova i Metohije jugoslovenski komunisti su, uopšte uzev, radili na organizacionom objedinjavanju ovog prostora. Ipak, kao recidiv prethodnih epoha u kojima se prostor Kosova i Metohije nalazio podeljen između interesnih sfera dve srpske kraljevine, komunisti Srbije i Crne Gore podjednako su baštinili pravo na delovanje u ovoj oblasti. Tokom 30-ih godina, tačnije do 1937, Okružni komitet KPJ za Metohiju sa sedištem u Peći u organizacionom smislu gravitirao je ka Podgorici, dok su komunisti u Kosovskoj Mitrovici pretežno sarađivali sa „Srbijancima“. Tako su se 1935. crnogorski komunisti obraćali "narodu posrbljene Metohije“ i „radnom narodu sela i grada Metohije“. ${ }^{15}$ Odnos rukovodstva PK KPJ za Crnu Goru prema Metohiji bio je određen svešću o relativno velikoj grupi crnogorskih naseljenika (autokolonista) u toj oblasti. S druge strane, partijske ćelije u Prištini, koje su obnovljene 1932, sarađivale su sa CK KPJ preko Okružnog komiteta KPJ u Nišu. ${ }^{16}$

Svoj rad u Metohiji komunisti su obnovili 1934. Mada je postojao Oblasni komitet (OK) za Kosovo i Metohiju, aktivnost komunista uglavnom se odvijala jedino u Peći i neposrednoj okolini. Otuda se tokom 1935. PK KPJ za Srbiju, kome je u tom trenutku pripadao OK KPJ za Kosovo i Metohiju, obraćao isključivo „radnom narodu grada i sela Metohije“, odnosno drugovima, radnicima i seljacima "grada Peći i sela Metohije“. ${ }^{17}$ Centralni komitet KPJ nastojao je da preko novoformiranog rukovodstva Okružnog komiteta KPJ za Metohiju - Milutin Božović, Boris (Boro) Vukmirović, Đoko Ačković, Joco Ljumović i Ilija Nikčević - pokrene partijski rad na Kosovu. Okružni komitet KPJ za Metohiju najpre je povezan sa PK KPJ za Crnu Goru, ali je ubrzo nakon utamničenja većeg broja crnogorskih komunista ostao gotovo u potpunosti izolovan. Čvršće povezivanje partijskih struktura na Kosovu sa PK KPJ za Srbiju, na čemu je radio Radovan Vuković, propalo je usled njegovog hapšenja 1936. Instruktor CK KPJ Petar Radović je po povratku s robije decembra 1936. reorganizovao OK KPJ za

${ }^{15}$ Arhiv Jugoslavije, fond Centralni komitet Saveza komunista Jugoslavije, zbirka Crna Gora (dalje AJ, CK SKJ, CG), I/18; I/19.

${ }^{16}$ A. Hadri, Komunistička partija Jugoslavije na Kosovu i Metohiji do Aprilskog rata 1941. godine, Tokovi revolucije, br. 5/1971, Beograd 1971, 370.

${ }^{17}$ Arhiv Jugoslavije, fond Centralni komitet Saveza komunista Jugoslavije, zbirka Srbija (dalje AJ, CK SKJ, SRB), I/85; I/86. 
Kosovo (Petar Radović - sekretar, Boris Vukmirović, Ramiz Đema, Andro Čukić i Joco Ljumović). ${ }^{18}$

Ideja narodnog fronta bila je do dolaska Vidaka Markovića u Peć sredinom 1936. gotovo nepoznata članstvu KPJ na Kosovu i Metohiji. ${ }^{19}$ Donevši nove smernice partijskog vrha, Krsto Popivoda je sredinom 1937. u Peći sarađivao sa predstavnikom partijskih organizacija na Kosovu i Metohiji Miladinom Popovićem. Njemu se tri meseca kasnije pridružio Moma Marković, koji se najpre na kratko zadržao u Kosovskoj Mitrovici, gde se nalazilo sedište Okružnog komiteta KPJ za Kosovo. U toku leta 1938. na Kosovu i Metohiji je u ime rukovodstva KPJ boravio Milovan Đilas. ${ }^{20} \mathrm{Na}$ sastancima kojima su prisustvovali predstavnici CK KPJ i članovi privremenog oblasnog rukovodstva, usvojeno je gledište o stvaranju jedinstvene organizacione strukture za Kosovo i Metohiju. Prema sećanju Mome Markovića, „u razgovoru s drugovima iz Peći“ predstavnici CK KPJ su se saglasili da "Kosovo i Metohija treba da - zbog specifičnosti položaja albanske manjine, terora i nacionalnog istrebljavanja, oduzimanja zemlje seljacima predstavljaju jedinstvenu teritoriju, jer je ta oblast po nacionalnom sastavu, ekonomiji i svim drugim atributima jedna celina i ne treba da živi podeljena između Crne Gore i Srbije“. Dogovoreno je da se obrazuje novi Oblasni komitet KPJ za Kosovo i Metohiju u sledećem sastavu: Miladin Popović (sekretar), Boris Vukmirović, Andro Čukić, Ramiz Đema, Ramiz Sadiku. Ovaj spisak nije konačno utvrđen, već je ostavljena mogućnost za naknadni ulazak novih članova, pre svega iz redova šiptarske nacionalne manjine. Osnivačka konferencija Oblasnog komiteta KPJ za Kosovo i Metohiju održana je 25. jula 1937. na Crnom vrhu nedaleko od Peći. Potvrđen je izbor novog rukovodstva, mada usled unutarpartijskih sukoba nisu prisustvovali delegati iz Prištine, Kosovske Mitrovice i Vučitrna. ${ }^{21}$ 1973, p. 286.

${ }^{18}$ M. Folić, $n$. d., 4-5.

${ }^{19}$ A. Hadri, $n$. d., 383.

${ }^{20}$ M. Djilas, Memoir of a Revolutionary, Harcourt Brace Jovanovich Inc, New York,

${ }^{21}$ Moma Marković navodi kako se deo Oblasnog komiteta priklonio Boži Miletiću, bratu Petka Miletića. Više: M. Marković, n. d., 102-105. Partijsko rukovodstvo donelo je početkom 1938. odluku o isključenju Petka Miletića, koji je preko Kaznionskog partijskog komiteta u sremskomitrovačkom zatvoru vodio „pseudorevolucionarnu politiku“. Više: Pregled istorije Saveza komunista Jugoslavije, 288-298. Pored Bože Miletića, za „trockizam" su bili optuženi pojedini rukovodioci u Peći, Kosovskoj Mitrovici, Prištini i Uroševcu. Među ovim „frakcionašima“ nalazio se Petar Radović, sekretar mesnog komiteta u Peći, koji je 1938. isključen iz Partije. Likvidacijom „petkovaca“ nije ostvareno jedinstvo unutar partijskog rukovodstva na Kosovu i Metohiji. Centralni komitet KPJ je 1940. doneo odluku da člana Oblasnog komiteta Andra Čukića kazni isključenjem iz Partije, zbog njegovog „oportunističkog držanja“ prema sindikalnom pitanju. Više: AJ, CK SKJ, SRB, I/87, str. 1-2; Izvori za istoriju SKJ, Peta zemaljska konferencija KPJ, tom I, knj. 10, 197, 295; M. Folić, n. d., 15-18. 
Tokom druge polovine 30 -ih godina Oblasni komitet KPJ za Kosovo i Metohiju je $u$ organizacionom smislu gravitirao ka Pokrajinskom komitetu KPJ za Crnu Goru. Otuda je član crnogorskog PK Krsto Popivoda kao predstavnik CK KPJ prisustvovao sastancima Oblasnog komiteta KPJ za Kosovo i Metohiju u Peći. U izvorima KPJ nema jasnih naznaka o tendencijama za ujedinjenje Kosova i Metohije i Crne Gore, ali su partijske strukture Kosova i Metohije priključene crnogorskom pokrajinskom komitetu.

U cilju „prodora među Arnaute“ komunisti su se posebno obraćali šiptarskoj manjini zahtevajući njihovo „nacionalno oslobođenje“, „povratak zemljišta oduzetog kolonizacijom“, „pravo na besplatno naseljenje na čitlucima za arnautsku sirotinju“, „pravo na narodni jezik“, „na škole i opštinske samouprave“, „slobodu veroispovesti i običaja“ itd. ${ }^{22}$ Moma Marković u svojim sećanjima navodi da je predložio izmeštanje sedišta Oblasnog komiteta KPJ za Kosovo i Metohiju iz Kosovske Mitrovice u Peć, gde je delovao veći broj starijih članova Partije. ${ }^{23} \mathrm{~S}$ druge strane, imajući u vidu nacionalnu strukturu Kosova i Metohije, u ovom predlogu možemo prepoznati nastojanje jugoslovenskih komunista da svoj rad usmere ka čvršćem povezivanju sa Šiptarima. S tim ciljem, partijsko rukovodstvo je početkom 1938. podržalo formiranje „Šiptarskog narodnog komiteta“, koji je trebalo da se bori za „albansku stvar" u jugoslovenskoj državi. ${ }^{24} \mathrm{U}$ izveštaju OK KPJ za Kosovo i Metohiju upućenom CK KPJ januara 1938. stoji kako „nacionalno pitanje u tom kraju je takvo da je težnja za otcepljenjem ogromna. Mase se nadaju da bi otcepljenjem od Jugoslavije i ujedinjenjem sa Albanijom uspele da stvore ujedinjenu Albaniju [...]. Dogovorili smo se da se tamo [na Kosovu i Metohiji] stvori arnautski narodni komitet koji bi se borio, oslanjajući se na demokratske snage Jugoslavije, protiv nacionalnog ugnjetavanja, za vođenje arnautskih škola, jače učešće Arnauta u samoupravnim telima, protiv dosadašnjeg načina 'agrarne reforme' koja je pogađala srednjeg seljaka a štedila imanje vakufa, begova i patrijaršije. [...] Nevolja je što nema nikakve literature na albanskom jeziku“. Dalje se navodi kako među Srbima „treba buditi njihov nacionalni ponos, pokretati ga u borbu, da srpski narod radi svoje slavne prošlosti treba da bude prvoborac za slobodu a ne pandur šačice beogradskih šićardžija i izdajnika". ${ }^{25}$ Međutim, uprkos snažno izraženoj podršci šiptarskom stanovništvu, nacionalna politika KPJ na Kosovu i

${ }^{22}$ Više: A. Hadri, Politika narodnog fronta na Kosovu i Metohiji, Tokovi revolucije, br. 6/1971, Beograd 1971, 27-38.

${ }^{23}$ M. Marković, n. d., 104-105.

${ }^{24}$ J. Pleterski, Nacije - Jugoslavija - revolucija, Beograd 1985, 364-365.

${ }^{25}$ Cit. prema: D. Lukač, Politika KPJ prema nacionalnom pitanju uoči Aprilskog rata i pred ustanak 1941. (Prilog pitanju), Prilozi za istoriju socijalizma, br. 7/1970, Beograd 1970, $18-19$. 
Metohiji nije dala očekivane rezultate. U rukovodstvu Oblasnog komiteta osim Ramiza Sadikua i Ramiza Đeme nije bilo komunista šiptarske nacionalnosti.

Prema rečima Mome Markovića jedan od glavnih problema na Kosovu i Metohiji bio je „kako da više Albanaca uđe u partijsko rukovodstvo. Bilo je mnogo teškoća zbog političke i kulturne zaostalosti ovog kraja, što je podsticao režim svojom politikom. Mislim da je jedna od teškoća bila i $\mathrm{u}$ tome što u politici Partije nije bila dovoljno naglašena razlika između srpskog naroda i velikosrpske politike koju je sprovodio režim. Tome su doprinele i nejasne direktive i proglasi, kao što je, na primer, bio proglas CK KPJ iz 1931. godine u kome se pozivaju svi narodi da se bore protiv diktature Hrvati, Slovenci, Makedonci, Mađari - svi narodi i narodnosti, samo ne srpski narod, pa nekako ispada kao da je srpski narod ugnjetač ostalih. Takav stav je na Kosovu značio dve otežavajuće okolnosti: sputavao je komuniste srpskog porekla da se više politički angažuju oko prodiranja Partije u albansku sredinu, a delovao je obeshrabrujuće i na same srpske komuniste“". ${ }^{26}$ Partijski dokumenti iz sredine 30 -ih godina zanemaruju postojanje Srba $u$ Metohiji, te se isključivo obraćaju „Arnautima“ i „Crnogorcima“. Na kraju jednog proglasa Oblasnog komiteta KPJ za Kosovo i Metohiju iz 1937. stoji: „Živela arnautska i crnogorska zajednička borba za slobodu i građanska prava! Živela zajednička borba svih porobljenih naroda Jugoslavije!“27 Isključivanje srpskog elementa iz borbe za nacionalna prava "porobljenih naroda“ ostavlja jasan utisak da su Srbi ugnjetačka nacija, čime je u potpunosti opravdana i podržana udružena borba ostalih naroda i nacionalnih manjina protiv zajedničkog neprijatelja - srpskog naroda.

Munjevitom akcijom započetom 1. septembra 1939. Nemačka je okupirala zapadne delove Poljske, našavši se istovremeno u ratu sa Velikom Britanijom i Francuskom. S druge strane, koristeći pravo obezbeđeno paktom Ribentrop-Molotov, sovjetska Crvena armija je 17. septembra 1939. umarširala u istočni deo Poljske. U ovoj „teškoj i baruta punoj međunarodnoj situaciji“ jugoslovenski komunisti su videli plodno tlo za "pokretanje sveopšteg rata“. Edvard Kardelj je istakao kako „fašistički imperijalisti nadiraju na najslabije tačke, po putu najmanjeg otpora“. Prema njegovom mišljenju, Kraljevina Jugoslavija je „zahvaljujući kapitulantskoj politici narodnih izdajica“, upravo „najslabija tačka na Balkanu“. ${ }^{28}$

Smatrajući da će vihor "novog imperijalističkog rata“ nesumnjivo ukinuti neutralnost Kraljevine Jugoslavije, Josip Broz je sredinom 1939. ocenio da "talijanske fašiste privlači naročito plodna Makedonija i Kosovo".

\footnotetext{
${ }^{26}$ M. Marković, $n$. d., 104.

${ }^{27}$ AJ, CK SKJ, SRB, I/86, str. 2.

${ }^{28}$ Proleter, br. 1, maj 1939, 11.
} 
S druge strane, veliku odgovornost za eksploziju separatizama u Kraljevini Jugoslaviji snosi „vladajuća velikosrpska buržoazija“, jer je svojom „hegemonističkom politikom" posrednim putem omogućila delovanje različitih fašističkih i nacionalističkih grupa u zemlji. ${ }^{29}$ Polazeći od čvrsto utemeljenog stava da u jugoslovenskoj državi „postoji nacionalno ugnjetavanje“, predstavnici KPJ smatrali su da zajednička država predstavlja „primamljiv zalogaj za fašističko-imperijalističke razbojnike Berlina i Rima“. ${ }^{30}$

Prema mišljenju komunista jugoslovenski režim je, usled spoljne opasnosti i „pritiska narodnih masa" u zemlji, bio primoran da načini određene korake u rešavanju gorućih problema u zajedničkoj državi. U nastojanju da se barem delimično reši hrvatsko pitanje, predstavnik Hrvatske seljačke stranke Vlatko Maček i predsednik jugoslovenske vlade Dragiša Cvetković potpisali su 26. avgusta 1939. sporazum o formiranju Banovine Hrvatske.

U okviru niza negativnih ocena izrečenih na račun sporazuma Cvetković-Maček, nezadovoljstvo komunista bilo je naročito izazvano time što se posle stvaranja Banovine Hrvatske nije pristupilo rešavanju problema ostalih „ugnjetenih naroda“ i nacionalnih manjina u Kraljevini Jugoslaviji. Na Prvoj konferenciji KPJ za Kosovo i Metohiju, održanoj u drugoj polovini 1939, postavljeno je pitanje: „Šta je sporazum donio nama na Kosovu i Metohiji u pola rešivši Hrvatsko pitanje, ne dotičući se ostalih nacionalnih pitanja [?]“ Kako je ocenjeno da sporazum Cvetković-Maček „nije ni dotakao" stanovništvo Kosova i Metohije, odlučeno je da se komunistima u toj oblasti „postavlja kao zadatak borba za proširenje sporazuma“. U rezoluciji ove konferencije komunisti su posebno istakli da se pored „borbe za izvojevanje demokratskih i nacionalnih prava u Jugoslaviji, nameće [...] borba za rešenje Arnautskog pitanja - najvažnijeg pitanja na Kosovu i Metohiji." Od jugoslovenskih vlasti zatraženo je da se „prestane sa dosadašnjim nečovječnim postupanjem prema Arnautskom narodu“ i da se „u borbu protiv Italijanskog i veliko Srpskog imperijalizma izvojuju nacionalna-politička i ekonomska i kulturna prava arnauta". Na konferenciji su jasno određeni najvažniji zadaci: „Da se prodre među arnautima i sa njima zajedno bori“, te da se „izdignu arnautski kadrovi i da se izdaje partiska literatura na arnautskom jeziku“. ${ }^{31}$ Pri tom prava srpskog naroda nisu navedena, niti je uvaženo postojanje bilo kog entiteta na Kosovu i Metohiji sem „arnautskog“.

Sa porastom ratne opasnosti na Balkanu tokom 1939-1941. rukovodstvo KPJ je upućivalo niže partijske organizacije na potiskivanje svih spornih pitanja koja su mogla ugroziti opstanak zajedničke države. Nacio-

\footnotetext{
${ }^{29}$ J. B. Tito, Sabrana djela, I-XXX, Beograd, 1981-1989, str. IV/192.

${ }^{30}$ Proleter, br. 1, maj 1939, 2.

${ }^{31}$ AJ, CK SKJ, SRB, I/87, str. 1-2.
} 
nalni i klasni momenat istisnut je na račun jugoslovenskog patriotizma. S tim u vezi komunisti Kosova i Metohije počeli su se, pored ostalog, obraćati srpskom narodu i ukazivati na pogubne rezultate politike aktuelnog režima. Na Drugoj oblasnoj konferenciji KPJ za Kosovo i Metohiju, održanoj najverovatnije sredinom jula 1940. u Vitomirici kod Peći, ${ }^{32}$ ocenjeno je kako nenarodna vlada [Dragiša] Cvetković-[Vlatko] Maček-[Anton] Korošec sprovodi politiku reakcije i nacionalnog ugnjetavanja Makedonaca, Crnogoraca i drugih naroda Jugoslavije, a produžuje politiku svojih prethodnika na Kosovu i Metohiji. Sprovodi politiku nečuvenog ugnjetavanja arnautskog naroda, trudi se da produbi jaz između doseljenika, Srba meštana i Arnauta i time razbije jedinstvo narodne borbe“. ${ }^{33}$

Prema mišljenju jugoslovenskih komunista "slobodu i ravnopravnost svih ugnjetenih naroda“ moguće je ostvariti jedino u „borbi protiv velikosrpskih hegemonista svih boja i njihovih agenata kako u redovima radničke klase tako i izvan njenih redova, kao i agenata stranih imperijalista, u prvom redu talijanskog vođstva crnogorske federalističke stranke kao i begova i barjaktara na Kosovu i Metohiji kao agenata raznih imperijalista". ${ }^{34}$

Mada je do sredine 1940. postignut „jedan mali uspeh“ među „arnautskom omladinom", ukupan rezultat nalazio se ispod očekivanih vrednosti. Stoga je "prodor među Arnaute i njihovo okupljanje oko KP" označeno kao „glavni zadatak OK i celog članstva“. Prema mišljenju komunista, „to se može uraditi tek pošto svaki član Partije bude imao ispravan stav po tom pitanju i taj stav prenosio na široke narodne mase. Treba arnautske radne mase povezati s naseljeničkom i ostalom sirotinjom u borbi za svakodnevne životne interese i odvojiti ih od uticaja begova, koji se nalaze na antinarodnoj liniji sa ostalom reakcijom". Posebno je istaknuto da partijski materijal treba izdavati na „arnautskom jeziku“. ${ }^{35}$

Teškoće $u$ radu oblasnog komiteta ogledale su se u povremenom „silasku s pravilne partijske linije“. U tom smislu, u rezoluciji Druge oblasne konferencije osuđena je direktiva PK KPJ za Crnu Goru, Boku, Sandžak, Kosovo i Metohiju od aprila 1940. o demobilizaciji. Ova „defetistička parola“, koja je „nanela veliku štetu“ i dovela do „slabljenja političkog uticaja na široke narodne mase“, odbačena je u korist konsolida-

${ }^{32}$ U radu Druge oblasne konferencije KPJ za Kosovo i Metohiju učestvovalo je oko 20 delegata. Izveštaj o radu Partije i referat o političkoj situaciji podneli su Miladin Popović i Boris Vukmirović. Na konferenciji je, pored ostalog, izabrano novo rukovodstvo Oblasnog komiteta i utvrđen sastav delegacije za Osmu pokrajinsku konferenciju KPJ za Crnu Goru, Boku, Sandžak, Kosovo i Metohiju.

${ }^{33}$ Izvori za istoriju SKJ, Peta zemaljska konferencija KPJ, tom I, knj. 10, str. 295.

${ }^{34}$ Isto, 321.

${ }^{35}$ Isto, 296-297. 
cije redova unutar KPJ i jačanja odbrambenih potencijala jugoslovenske države.

Pored navedenog, predviđeno je da oblasno rukovodstvo redovno pruža pomoć „u radu i materijalu“ svim potčinjenim organizacijama i „sprovodi kontrolu“, potom posveti veću pažnju „boljševičkom uzdizanju kadrova“, razvije "osećaj odgovornosti“ i podstiče "više samoinicijative“ u radu mesnih komiteta, pojača aktivnost sindikata i „rad među ženama“. Od članstva je zahtevano redovno izmirenje članarine, razvijanje „široke organizacije Narodne pomoći“ i „čuvanje časnog zvanja člana Partije kako u svakidašnjoj borbi tako i pred klasnim neprijateljem" ${ }^{36}$

U perspektivi KPJ i njenom odnosu prema kosovskometohijskoj oblasti posebno mesto pripadalo je Metohiji, koja je posmatrana kao jedan od centara jugoslovenske industrije. $\mathrm{Na}$ Osmoj pokrajinskoj konferenciji KPJ za Crnu Goru, Boku, Sandžak, Kosovo i Metohiju, ${ }^{37}$ održanoj sredinom avgusta 1940, naglašeno je kako je potrebno „odmah pojačati postojeće part[ijske] org[anizacije] u svim mjestima, a naročito u industrijskim krajevima (Boki, Metohiji). Bez savladavanja ovog glavnog organizacionog zadatka nemogućni su pravilan razvoj Partije i izvršenje zadataka koji pred njom stoje“. ${ }^{38}$

Mada u ovom trenutku nije posebno raspravljano o organizacionim problemima na Kosovu i Metohiji, postavljeno je pitanje promene statusa partijskih struktura u toj pokrajini. ${ }^{39} \mathrm{~S}$ tim u vezi Josip Broz je posle okončanja rada konferencije na margini originalnog teksta rezolucije uneo komentar: „Metohija direkt[no] sa CK[KPJ]“. ${ }^{40}$ Predlogom o neposrednom vezivanju Metohije za Centralni komitet izraženo je mišljenje u korist izdvajanja ove oblasti iz okvira OK KPJ za Kosovo i Metohiju, odnosno PK za Crnu Goru, Boku, Sandžak, Kosovo i Metohiju. Ove tendencije imale su korene u stavovima pojedinih komunista iz Podgorice i Peći, ali i vrha Partije, prema kojima Metohija predstavlja posebnu oblast, odnosno pokrajinu. Analizom do sada poznatih izvora nije moguće utvrditi da li su i u kojoj

${ }^{36}$ Isto, 297-298.

${ }^{37}$ U trodnevnom radu Osme pokrajinske konferencije KPJ za Crnu Goru, Boku, Sandžak, Kosovo i Metohiju učestvovalo je oko 30 delegata (četiri iz Oblasnog komiteta za Kosovo i Metohiju). Politički i organizacioni izveštaj podneli su Blažo Jovanović i Krsto Popivoda. O radu u sindikatima govorio je Božo Ljumović, dok je referat o radu na selu podneo Ivan Milutinović. Branko Petričević izneo je rezultate rada Partije među ženama. Na konferenciji je izabrano novo pokrajinsko rukovodstvo i utvrđen spisak delegata za Petu zemaljsku konferenciju KPJ. Poseban ton radu konferencije davalo je prisustvo generalnog sekretara KPJ Josipa Broza.

${ }^{38}$ AJ, CK SKJ, CG, I/8, str. 2.

${ }^{39}$ Izvori za istoriju SKJ, Peta zemaljska konferencija KPJ, tom I, knj. 10, str. 197.

${ }^{40}$ Isto, 580, nap. br. 634. 
meri preduzimani konkretni koraci radi realizacije ove ideje. Ipak, potonji partijski dokumenti svedoče o sporadičnom samostalnom istupanju članova OK u ime Metohije. Tokom diskusije na Petoj zemaljskoj konferenciji KPJ (1940) Boris Vukmirović je predstavljao Metohiju, dok je Miladin Popović govorio u ime Kosova i Metohije. Josip Broz je potvrdio da je pre ove konferencije „Metohija tražila neposrednu vezu sa CK KPJ“. ${ }^{41}$ Nedosledan odnos partijskog rukovodstva prema organizacionom pitanju Kosova i Metohije, Crne Gore i Srbije tokom druge polovine 30-ih godina unosio je dodatne nedoumice. Tako je Josip Broz u svom izveštaju iz septembra 1939, govoreći o brojnom stanju članova Partije u jugoslovenskim pokrajinama, pored ostalog, naveo: „U Srbiji ima oko 800 članova, [...], u Vojvodini oko 300, u Bosni [i Hercegovini] 170, u Metohiji 100". U istom dokumentu, međutim, rečeno je da se unutar KPJ nalazi „Oblasni komitet u Metohiji (Kosovo)“, što upućuje na zaključak o postojanju jedinstvene organizacije u toj oblasti. Takođe, u nazivu „Pokrajinski komitet za Crnu Goru“ nedostaju Boka, Sandžak, Kosovo i Metohija. ${ }^{42}$ U partijskoj štampi moglo se videti da KPJ čine organizacije u Sloveniji, Srbiji, Crnoj Gori, Bosni i Hercegovini, Hrvatskoj i Metohiji. ${ }^{43}$

Potkraj 1940. u kombinatorici Centralnog komiteta o preuređenju partijskih struktura u zemlji, Metohiji je nedvosmisleno pridodato Kosovo. Govoreći o problemima rada u Metohiji i potrebi organizacionog objedinjavanja Kosova i Metohije u zasebnu celinu, delegat Boris Vukmirović je na Petoj zemaljskoj konferenciji KPJ, održanoj oktobra 1940. u Dubravi nedaleko od Zagreba, ${ }^{44}$ pobrojao osobenosti partijskog delovanja u ovoj oblasti. Najpre, „veza s PK C[rne] Gore nije dovoljna, jer materijal mnogo zakašnjava“. Sledeći argumenti su ekonomska struktura stanovništva i „politički položaj“ šiptarske manjine. Prema rečima Borisa Vukmirovića, na Kosovu i Metohiji živi oko „500 000 Arnauta, koje reakcija iskorišćava“, te oni predstavljaju veliku „rezervu za reakciju“. Zatim, „prijeti opasnost od Italije“. Neprohodnost terena dodatno ometa delovanje komunista: „zimus [1939/1940] 3 mjeseca nije se ništa dobilo od PK C[rne] Gore“ ${ }^{45}$ Nakon ini-

\footnotetext{
${ }^{41}$ Isto, 189-217.

${ }^{42}$ AJ, KI, 1939/11.

${ }^{43}$ Proleter, br. 1-2, januar-februar 1940, 3.
}

${ }^{44}$ U radu Pete zemaljske konferencije KPJ učestvovalo je oko 1.500 delegata. Kako je poslednji kongres KPJ održan 1928, rukovodstvo KPJ je 1937. u Kominterni isticalo potrebu sazivanja partijskog kongresa. Ova ideja aktivirana je septembra 1940, ali ju je KI odbila „uslijed ozbiljne opasnosti da policija otkrije održavanje kongresa“. - J. B. Tito, n. d., VI/201.

${ }^{45}$ Slični argumenti i zahtevi izneti su na Prvoj oblasnoj konferenciji KPJ za Kosovo i Metohiju 1939, kada je odlučeno da se „postavi pitanje autonomije OK PK-u [Crne Gore] koji će to sprovesti. Autonomija nam je potrebna“ zato „što nam je pomoć PK usljed nepoznavanja terena i specifičnosti prilika nedovoljna“. Takođe, navedeno je kako su „komunika- 
cijative Josipa Broza da se razmotri zahtev Borisa Vukmirovića i Miladina Popovića o organizacionom izdvajanju i objedinjavanju Kosova i Metohije, iznet avgusta 1940. na Osmoj pokrajinskoj konferenciji KPJ za Crnu Goru, Boku, Sandžak, Kosovo i Metohiju, CK KPJ je doneo odluku: „Predlog sekr[etara] [Josipa Broza] da se Metohija i Kosovo pretvore u Obl[asni] komitet s posebnom vezom s CK [KPJ] prima se jednoglasno". ${ }^{46}$

Uprkos navedenoj odluci CK koja je podrazumevala organizacionu individualizaciju Kosova i Metohije u odnosu prema ostalim pokrajinskim komitetima unutar KPJ, istupanje pojedinih visokih partijskih funkcionera svedoči o odsustvu jedinstvenog stava o ovom pitanju. Govoreći o problemu uzdizanja kadrova, Josip Broz je u svom referatu predstavljenom na Petoj zemaljskoj konferenciji KPJ, zaključio kako najslabije stoje „one pokrajine u kojima donedavna nije bilo partijske organizacije, kao, npr., Makedonija, Bosna i Hercegovina, Metohija i Dalmacija“. ${ }^{47}$ Dakle, u ovom konteksu Metohija je posmatrana $u$ ravni sa ostalim jugoslovenskim pokrajinama. S druge strane, Moša Pijade je u svojim tezama o nacionalnom pitanju izostavio Kosovo i Metohiju iz skupa „istorijski formiranih zemalja i pokrajina“ $u$ Kraljevini Jugoslaviji. ${ }^{48}$ Uopšte uzev, na Petoj zemaljskoj konferenciji KPJ nije ozbiljnije govoreno o Kosovu i Metohiji.

U godinama uoči Aprilskog rata u Kraljevini Jugoslaviji (19371941) komunisti nisu zvanično podržavali albanski iredentistički pokret, ali su u svojoj retorici zadržali nedovoljno jasne parole o samoopredeljenju nesrpskih naroda, koje su zapravo predstavljale kontinuitet sa ranijim separatističkim tendencijama. O pitanju odnosa prema šiptarskom narodu $\mathrm{u}$ Kraljevini Jugoslaviji partijsko rukovodstvo je zauzelo stav da treba podržati njihovu borbu „za slobodu i ravnopravnost" u okvirima zajedničke države. Trebalo je podupreti pokret „arnautskih manjina na Kosovu, u Metohiji i Sandžaku“, ali istovremeno delovati „protiv talijanskih agenata koji u tim krajevima nastoje raznim obećanjima obmanuti ugnjetene Arnaute i izazvati ratni sukob u tom dijelu Jugoslavije“. S tim u vezi, komunisti su pozivali na „borbu protiv kolonizatorskih metoda srpske buržoazije u tim oblastima i protjerivanje svih onih koloniziranih elemenata pomoću kojih srpska buržoazija ugnjetava makedonske, arnautske i druge narode“. Miladin Popović, politički sekretar OK KPJ za Kosovo i Metohiju, govorio je kako su kolonisti „stub [srpske] hegemonije“. ${ }^{49}$ Zanemarivanjem činjenice o velikom broju

cione veze loše“, te da se tokom „tri meseca preko zime“ ne mogu uspostaviti „veze sa PK“. AJ, CK KPJ, SRB, I/87, str. 2.

${ }^{46}$ Izvori za istoriju SKJ, Peta zemaljska konferencija KPJ, tom I, knj. 10, 197-198.

${ }^{47}$ Isto, 32.

${ }^{48}$ Isto, 384.

${ }^{49}$ Isto, 213. 
autokolonista iz Crne Gore nastanjenih u Metohiji jednostavnom uzurpacijom obradivih površina i pašnjaka, ${ }^{50}$ stiče se utisak da je jedino bilo važno istaći one momente koji će ujediniti nesrpske narode $u$ borbi protiv „velikosrpskog hegemonizma“.

U okviru oblasne partijske organizacije KPJ za Kosovo i Metohiju, novembra 1940. postojali su mesni komiteti u Kosovskoj Mitrovici, Đakovici, Prizrenu i Peći, gde se nalazilo i sedište Oblasnog komiteta. Prema izveštaju Borisa Vukmirovića, unutar četiri sreza delovale su partijske ćelije, dok su dva sreza imala „oml[adinske] i vaspitne grupe kod Arnauta“. Broj članova Oblasnog komiteta iznosio je 239: „55\% selj[aka], 30\% rad[nika], $15 \%$ int[elektualaca]".

Jedan od problema u kadrovskoj politici KPJ na Kosovu i Metohiji predstavljao je slab odziv žena. Unutar krutih patrijarhalnih okvira na Kosovu i Metohiji, bez obzira na versku i nacionalnu pripadnost, nije se blagonaklono gledalo na učešće žena u politici, pogotovo ukoliko je reč o partiji sa revolucionarnim predznakom. O tome svedoči izveštaj Borisa Vukmirovića, u kome se navodi kako od 12 žena komunista u Oblasnom komitetu, njih „10 dobije batine“" po povratku sa partijskog sastanka.

Krajem novembra 1940. na Kosovu i Metohiji bilo je samo 25 komunista albanske nacionalnosti (2 u rukovodstvu) od ukupno 239 članova Oblasnog komiteta. ${ }^{51}$ Upadljiva nesrazmera između zastupljenosti Šiptara u komunističkom pokretu i nacionalne strukture stanovništva na Kosovu i Metohiji navodi na zaključak o neuspehu nacionalne politike KPJ u odnosu prema albanskom pitanju. S druge strane, nosioci politike i partijskog rada u ovoj oblasti bili su Srbi, tačnije komunisti naseljenici, prema kojima je šiptarsko stanovništvo bilo naročito nepoverljivo. Rad ovih komunista naročito je aktiviran posle isteka deset godina od naseljavanja, jer je tada dodeljeni posed prelazio u njihovo punopravno i trajno vlasništvo. Tako su prve partijske organizacije formirane u kolonijama koje su najranije naseljene: Vitomirica, Dobruša, Vrelo, Suvi Do i drugim..$^{52}$

U kontekstu odbrane Kraljevine Jugoslavije od daljeg nemačkog i italijanskog prodora KPJ je u svojoj propagandi „pogađala neuralgične tačke" $\mathrm{u}$ istoriji srpskog i ostalih naroda $\mathrm{u}$ zemlji. ${ }^{53}$ Da su jugoslovenski komu-

${ }^{50}$ Z. Janjetović, $n$. d., 335.

${ }^{51}$ Izvori za istoriju SKJ, Peta zemaljska konferencija KPJ, tom I, knj. 10, str. 197198; A. Hadri, Peta zemaljska konferencija i organizacija KPJ na Kosovu, Peta zemaljska konferencija Komunističke partije Jugoslavije, zbornik, Zagreb 1972, 296.

${ }^{52}$ M. Obradović, Stav KPJ prema agrarnom i seljačkom pitanju na Kosovu 19181941. godine. Separat, Zagreb 1980, 231-232.

${ }^{53}$ Obraćajući se narodu u Srbiji, CK KPJ je, pored ostalog, evocirao uspomene iz Prvog svetskog rata: „Srbi, godine 1915. Mekenzenove trupe pregazile su Srbiju. 'Drang nach Osten' vodi dolinom Morave" (AJ, KI, 1938/17). 
nisti nesumnjivo znali šta za srpski narod u duhovnom smislu predstavlja prostor Kosova i Metohije potvrđuje apel CK KPJ upućen u atmosferi iščekivanja „novog imperijalističkog rata“ posle „Anšlusa“ (12. mart 1938): „Kao što je poslije poraza na Marici došlo Kosovo, tako bi i posle pada Ljubljane i Zagreba došao na red Beograd “. ${ }^{54} \mathrm{Na}$ opštem planu, posmatrano $\mathrm{u}$ odnosu prema nacionalnoj politici KPJ u periodu do 1935, partijsko rukovodstvo je ublažilo svoje negativne stavove o jugoslovenskoj državi, Srbiji i srpskom narodu. Ipak, u retorici jugoslovenskih komunista opstali su određeni duboko ukorenjeni antisrbijanski, pa i antisrpski stereotipi, formirani tokom protekle dve decenije. Krajem 1939. Josip Broz je zapisao kako su "vlast i hegemoniju za 20 godina“ postojanja jugoslovenske države imali „Srbi, koji su prema ostalim nacionalnostima primenjivali gotovo polukolonijalne metode". ${ }^{55}$ Svest o Srbima kao ugnjetačkom narodu opstala je unutar krugova KPJ u vidu sveprisutne opomene. Otuda je partijsko rukovodstvo smatralo preuranjenim pokretanje pitanja Bosne i Hercegovine, Kosova i Metohije, Sandžaka, Vojvodine, Srema i krajeva naseljenim srpskim stanovništvom u Hrvatskoj. ${ }^{56} \mathrm{U}$ nacionalnoj politici KPJ u međuratnom periodu prava srpskog naroda u jugoslovenskoj državi nisu navedena, srpski prostor nije definisan, granice Srbije nisu jasno određene.

Posmatrano iz ugla partijskog vrha, na Kosovu i Metohiji najvažnije je bilo uputiti „široke mase albanskog naroda“ na saradnju sa komunistima. Isticanje „nacionalnih prava“ šiptarske manjine, stvaranje Kosovskog komiteta (1923), načelno i principijelno priznavanje prava na samoopredeljenje do potpunog otcepljenja (1928), potom formiranje Oblasnog komiteta KPJ za Kosovo i Metohiju (1937) i Šiptarskog narodnog komiteta (1938), direktno povezivanje Oblasnog komiteta sa Centralnim komitetom KPJ (1940) itd., jedino je imalo za cilj povezivanje KPJ sa „Arnautima“. Dalekosežni rezultati nacionalne politike KPJ na Kosovu i Metohiji u međuratnom periodu išli su u prilog osipanja srpskog nacionalnog korpusa u toj oblasti. Ovaj trend, prisutan $\mathrm{u}$ toku Drugog svetskog rata i nastavljen $\mathrm{u}$ socijalističkoj Jugoslaviji, ${ }^{57}$ ugrađen je u sveukupnu politiku Partije.

\footnotetext{
${ }^{54}$ Isto.

${ }^{55}$ J. B. Tito, n. d., V/201.
}

${ }^{56}$ B. Petranović, Jugoslovensko iskustvo srpske nacionalne integracije, Beograd 1993, 43.

${ }^{57}$ Prema odluci partijskog vrha i jugoslovenskih vlasti iz 1945. stanovništvu doseljenom iz Albanije u toku Drugog svetskog rata - procenjuje se da se radi o 80.000 do 300.000 ljudi - dopušteno je da se trajno nastani na Kosovu i Metohiji. Istovremeno je pripadnicima srpskog naroda zabranjen povratak na svoja imanja. Albanskim porodicama dodeljeno je 21.079 hektara zemlje, koja se u pravnom smislu još uvek nalazila u vlasništvu prognanih Srba. Neposredno posle rata spor oko zemljišta vodilo je oko 10.000 Srba i Crnogoraca. - M. Pavlović, n. d., 161-162. 
Dušan Bojković

THE NATIONAL POLICY OF THE COMMUNIST PARTY OF YUGOSLAVIA
AT THE KOSOVO AND METOHIJA 1937-1941

Summary

During the Interwar period, Yugoslavia was viewed by the communists as an expression of will of the imperialist forces, that is to say, the product of the World War I. National policy of the Communist party of Yugoslavia (CPY) was based on the thesis of the hegemonism of Serbian people and the oppression towards the remaining non-Serbian peoples and national minorities.

Organizational structure of CPY acknowledged territorial boundaries between historic provinces or regions which, by their geographic position, history and demographic structure, were set apart from one another. According to the leadership of the Party, during the thirties, area of Kosovo and Metohija indisputably represented a unique entity. Although, the question of incorporating Kosovo into "Serbia", and Metohija into Montenegro, remained open. This distribution of "spheres of influence" can be recognized in the activity of communists on terrain: party cells in Peć were directed towards cooperating with Podgorica and Cetinje, while the communists from Central Serbia sent their representatives to Kosovska Mitrovica. At the eve of World War II, balance had shifted towards policy of uniting the party structures at Kosovo and Metohija, which was expressed in the forming of the Regional committee, in Peć, in 1937. During this period, the Regional committee of CPY for Kosovo and Metohija, gravitated towards Montenegrin Regional committee. At the end of 1940. a final stand that this region is not to be divided, was made, which was further augmented by direct connection of Regional committee for Kosovo and Metohija with Central committee of CPY. National policy of CPY concerning Kosovo and Metohija was directed towards linking with shqiptar population and its struggle for "national liberation", while the rights of Serbian population in that area were completely neglected. 